\title{
LETRAS GEÓRGICAS
}

\section{Olvido GARCÍA VALDÉS}

\section{1}

La hora pastoral

de los animales en hilera. Atardece

vaca y ternero y vaca y vaca.

Muge, no porque la oiga, sino porque la veo

la precisa línea de la testa levantada

la del morro al mugir, los campos pastorales

caballos y potrillos cerca de la ciudad.

Be calm, decía en una lengua no

suya, animal ser de la calma.

brillo

verde amarillo sin alimento

solo humedad

$$
\begin{aligned}
& \text { (no densos } \\
& \text { no los profundos } \\
& \text { no luz alegre del verde) }
\end{aligned}
$$

viene de abajo

lo enciende el agua

llega de fuera, casi sin humus 
Tropelías. Revista de Teoría de la Literatura y Literatura Comparada, 21 (2014) 209

3

cabeza

de gato se llamaba la canción

la cantaba ensamblando tablas

de la caja, la cantaba y eran

las vetas de madera notas

de la canción, cabeza de gato

el tarareo, viruta dulce

ya sin letra la madre.

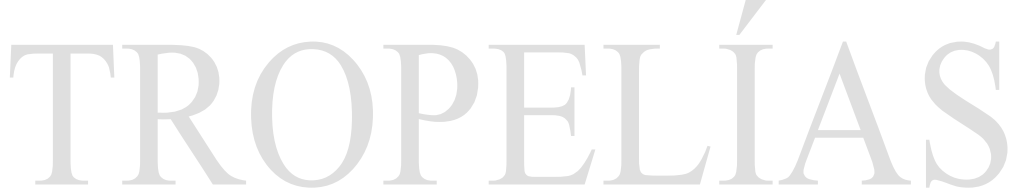

